\title{
Optimization of $\mathrm{ScCO}_{2}$ Extraction of Rambutan Seed Oil Using Response Surface Methodology
}

\author{
Nuttawan Yoswathana
}

\begin{abstract}
Seed of rambutan as a waste of products from the canned fruit industry and was extracted by supercritical carbon dioxide $\left(\mathrm{ScCO}_{2}\right)$ using $\mathrm{CO}_{2}$ as a solvent, maceration and soxhlet extraction using ethanol as the solvent. An optimization study of $\mathrm{ScCO}_{2}$ extraction using response surface methodology was performed and 3D response surfaces were plotted from the mathematical models. The optimal conditions based on combination responses were: pressure $\left(X_{1}\right)$ at $34.8 \mathrm{MPa}$, temperature $\left(X_{2}\right)$ at $56.7^{\circ} \mathrm{C}$, the amount of ethanol $\left(X_{3}\right)$ in volume $14.5 \mathrm{ml}$. These optimum conditions of percent oil yield of 30.38. Therefore, it is considered that the $\mathrm{ScCO}_{2}$ extraction is competitive with conventional extraction as shorter extracting times, high percent oil yield, less organic solvent and eco-environmental friendly. The extracted oil could be used in the cosmetic and food industry.
\end{abstract}

Index Terms - Rambutan seed, supercritical carbon dioxide extraction, fatty acid, response surface methodology.

\section{INTRODUCTION}

Rambutan (Nephelium lappaceum L.) is one variety of the attractive tropical fruit in Thailand which popular cultivars are Rongrien and Seechompoo. They are usually eaten fresh. The rambutan canned fruit industry is well-established in Thailand and has become in the leading of producer and exporter of the fruit. During processing, rambutan are peels off and removed seeds which remain as a wasted by product of the canned fruit industry. There are potential for exploitation of these seed by-products. Recently, phenolic compounds of this fruit have been found to be of increasing interest. Its pulp contains polyphenol (gallic acid) and possesses low antioxidant activity [1]. Meanwhile, rambutan seeds used as a natural sustainable source of fat and oil that "waste products" could provide the seed oil in the pharmaceutical and food industry with a new source of edible oils. Many studies on seed oils properties and their application from variety of plants are reported such as gumbo seed [2], Mango (Mangifera indica L.) Seed [3], Canarium pimela L. kernel [4], Egyptian mango seed [5], longan (Dimocarpus longan), and rambutan (Nephelium lappaceum) [6].

Conventional extraction methods, such as marceration, soxhlet which are the organic solvent extraction, have been used to extract bioactive compounds and oil from plant materials for a long time. These methods usually require a

Manuscript received April 5, 2013; revised May 31, 2013. This work was financial supported in part by the National Research Council of Thailand $(N R C T)$, Thailand Toray Science Foundation (TTSF) and placed by Faculty of Engineering, Mahidol University.

Nuttawan Yoswathana is with the Mahidol University, Faculty of Engineering, Department of Chemical Engineering, Salaya, Thailand (e-mail nuttawan.yos@mahidol.ac.th). long time, a large amount of solvent or high temperature [7]. Therefore, novel extraction techniques with high efficiency and eco-environmental friendly are highly desirable.

Supercritical carbon dioxide $\left(\mathrm{ScCO}_{2}\right)$ extraction is one of novel technique which has received a great deal of attention. According to its operation, it is usually performed at low temperatures, costing short extraction time and a small amount of solvent [8], [9]. Supercritical fluids are unique in that the density is similar to a liquid while the diffusion and viscosity is between a gas and liquid [10]. Previously, $\mathrm{ScCO}_{2}$ has been used to extract flavonoids and phenolics from a wide range of plants [11]-[14], carotenoids [15], seed oil [16] and essentential oils [17]-[19]. Generally, addition of a small amount of a liquid polar modifier (methanol or ethanol) can significantly enhance extraction efficiency of flavonoids and phenolics [14]. Furthermore, $\mathrm{ScCO}_{2}$ could be easily separated from extracted substances [20]-[22].

The response surface methodology (RSM) is defined as the experimental design using the statistic method that uses quantitative data from suitable experimental design to reduce number of experimental trials needed to evaluate multiples parameters and their interactions. RSM has been achievably applied for optimizing conditions in food research [23]-[26]. This work aimed to optimize the $\mathrm{ScCO}_{2}$ extraction of oil from rambutan seed conditions, including temperature, pressure and the amount of ethanol as co-solvent using RSM. The response variable examined the yields of oil. The efficiency yield of the oil was also studied under different extraction methods.

\section{MAterials AND METHODS}

\section{A. Preparation of Plant Sample}

Rambutan seeds were taken from the canned fruit industry. The seeds were washed and cut into two halves. The kernels were removed manually from the seeds and dried in the oven at $60^{\circ} \mathrm{C}$ for 6 hours. Then, the rambutan seeds were ground into particles ranging from 0.2 to $1.2 \mathrm{~mm}$ in size by a hammer mill and being forced through a sieve.

\section{B. Extraction of Total Oil Using Maceration}

The rambutan seeds ( $20 \mathrm{~g}$ ) were added to $150 \mathrm{ml}$ of hexane for solid to solvent ratio of $1: 15$ in a $500 \mathrm{~mL}$ flask, respectively and mixed on a magnetic stirrer for 2,4,6 and 8 hours at room temperature $\left(28^{\circ} \mathrm{C}\right)$. The supernatant was passed through Whatman filter paper (no.1). All filtrates were evaporated under vacuum at $60^{\circ} \mathrm{C}$ using a rotary evaporator (Buchi, Switzerland). The volume of sample adjust to $25 \mathrm{ml}$ using HPLC grade ethanol extracted and stored in refrigerator until analysis. 


\section{Extraction of Total Oil Using SOXHLET}

Soxhlet extractions were carried out in triplicate using 20 g (dry weight) rambutan seed powder with $300 \mathrm{ml}$ of $95 \%$ ethanol for for 2,4,6 and 8 hours. Temperature during soxhlet extraction was set at $78^{\circ} \mathrm{C}$. The extracted oil was evaporated under vacuum at $40^{\circ} \mathrm{C}$ at pressure $335 \mathrm{~mm} . \mathrm{Hg}$ using a rotary evaporator (Buchi, Switzerland). The extracted sample was evaporated and stored it in the refrigerator for analysis.

\section{Supercritical Carbon Dioxide $\left(\mathrm{ScCO}_{2}\right)$ Extraction Using Various Conditions}

The rambutan seeds ( $20 \mathrm{~g}$ ) were filled in a cloth bag and put into the extraction vessel of $\mathrm{ScCO}_{2}$ extractor (SIB, Germany). Response surface methodology (RSM) was employed to optimize the operating conditions of $\mathrm{ScCO}_{2}$ technique to obtain a high extraction yield. The studied parameters and their concentration ranges were: pressure $\left(\mathrm{X}_{1}\right)$ at $15,30,45 \mathrm{MPa}$, temperature $\left(\mathrm{X}_{2}\right)$ at $30,50,70^{\circ} \mathrm{C}$, amount of co-solvent (ethanol) $\left(\mathrm{X}_{3}\right)$ in volume $0,10,20 \mathrm{ml}$. The $\mathrm{CO}_{2}$ flow rate was constant at $2 \mathrm{~kg} / \mathrm{h}$ and extraction times of $2 \mathrm{hr}$. The oil was collected at the end of the extraction and stored it in the refrigerator for analysis.

\section{E. Statistical Analysis}

The results were expressed as mean of triplicate determination \pm standard deviation and each set of yields was average.

\section{RESULTS AND DISCUSSIONS}

\section{A. Types of Solvent}

The effect of types of solvent (hexane and ethanol) on the extracts yield using maceration technique was studied as shown in Fig. 1. It increases with increasing extraction time due to contact more times and due to the fact that the total extract yield kept on increasing with polarity of organic solvent, the extracts yield in ethanol (polar) was much higher than that of hexane (non-polar) and did experiment $6 \mathrm{~h}$ to get the highest yield of $22.16 \%$. Hence, it could do experiment only $4 \mathrm{~h}$, because of a small amount increasing extracts yield.

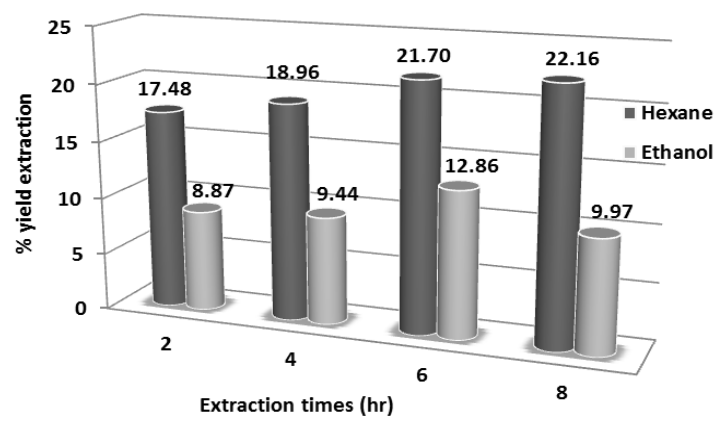

Fig. 1. Effect of solvents on the extracts yield of maceration at solid to solvent ratio $(\mathrm{w} / \mathrm{v})$ of $1: 15$ and various extraction times.

\section{B. Comparison of Maceration and Soxhlet Techniques}

The comparison of maceration and soxhlet techniques at solid to solvent ratio $(\mathrm{w} / \mathrm{v})$ of $1: 15$ and using $95 \%$ ethanol was investigated as viewed in Fig. 2. The influence of temperature on extracts yield of rambutan seed at various times of soxhlet and maceration demonstrated that percent oil yield of soxhlet was higher than that of maceration for all times. The result of soxhlet had trend to nearly $30 \%$ oil yield at anytimes from 2 to $8 \mathrm{hr}$. Therefore this technique did experiment only $2 \mathrm{~h}$ for the high percent oil yield of 28.90 . While maceration technique could extract the highest percent oil yield only 22.16 with a longer extraction time for $8 \mathrm{~h}$. According to increasing temperature [22], it helps to enhance both the solubility of solute and the diffusion coefficient. Heating also might soften the plant tissue. Thus, the extraction could be developed by increasing temperature.

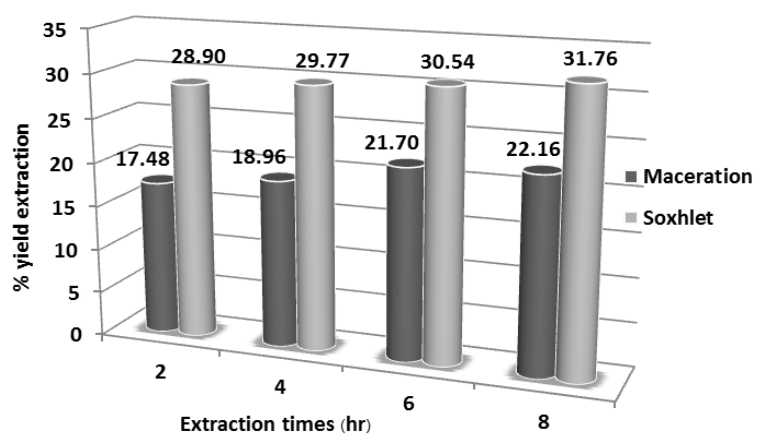

Fig. 2. Comparison of oil yield from maceration and soxhlet

\section{Optimization of Important Factors for Supercritical Carbon Dioxide (ScCO2) Extraction by RSM}

Response surface methodology was a good tool for optimization of extraction conditions [23]-[26]. The experimental data of percent oil yield from rambutan seed using $\mathrm{ScCO}_{2}$ were used to calculate the coefficients of the second- order polynomial in equation (1). The coefficient of determining $\left(R^{2}\right)$ was 0.895 , indicating adequate accuracy. The application of RSM yielded the following regression equation (1) which was an empirical relationship between percent oil yield extraction $(Y)$ and the test variables in code units i.e. $X_{1}, X_{2}$, and $X_{3}$ were pressure (MPa), temperature $\left({ }^{\circ} \mathrm{C}\right)$ and amount of co-solvent (ethanol) (ml), respectively:

$$
\begin{aligned}
& \hat{Y}=-69.8421+1.9480 x_{1}+1.7429 x_{2}+2.7173 x_{3} \\
& -0.0268 x_{1} 2-0.015 x_{2} 2-0.0663 x_{2} 2+0.0028 x_{1} x_{2} \\
& -0.0194 x_{1} x_{3}-0.0069 x_{2} x_{3}
\end{aligned}
$$

Based on the above findings, an optimization study was performed to 3D surface plot in Fig. 3-5.

From Fig. 3, pressure and volume of $95 \%$ ethanol affected to extraction of percent oil yield from rambutan seeds. The best conditions for experiment of $\mathrm{ScCO}_{2}$ extraction as follows: pressure $30 \mathrm{MPa}$, temperature $56.7^{\circ} \mathrm{C}$, volume of $95 \%$ ethanol $10 \mathrm{ml}$ gave percent oil yield of 28.42 , the result presented that percent oil yields increased as pressure increases as a result of increased solubility of oil in solvent from 20 to $30 \mathrm{MPa}$. Then rising pressure up to $40 \mathrm{MPa}$, it decreased due to effect of high pressure could be degraded extracted oil yield oil [24], [25].

In this study, Fig. 4 showed that it seemed to increasing temperature lead to increase oil yield from 30 to $50^{\circ} \mathrm{C}$. After increasing temperature up to $70^{\circ} \mathrm{C}$, it was inversely with increasing temperature. This occurrence might be due to the 
applied high temperature, which decomposed characteristic of oil [22]. Also, pressure and temperature have a significant effect of oil yield extraction from rambutan seeds. According to Wei et al. (2009) [24], the higher temperature and pressure would cause softening of the plant tissue, and increasing the solubility of oil from rambutan seeds, which improves the rate of diffusion, thus giving a higher rate of extraction [23]. Also, the experiment should be operated at the top conditions of 3D-plotted curve for optimum conditions for oil extraction.

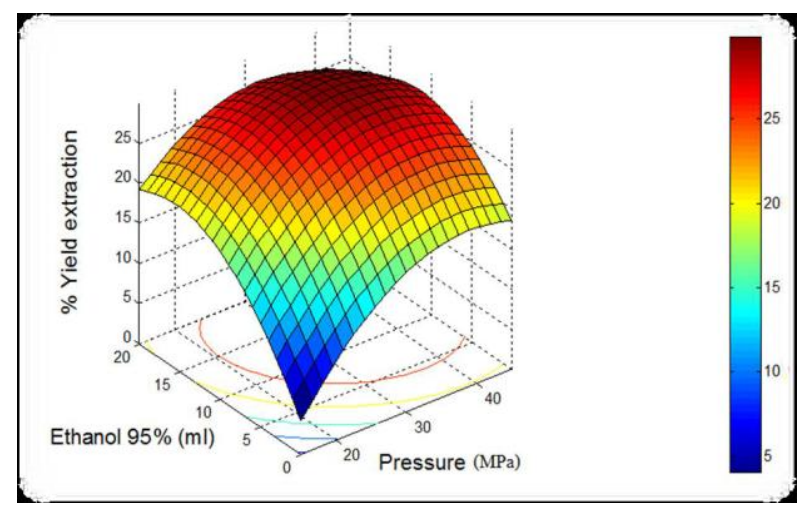

Fig. 3. Surface plot of pressure and volume of $95 \%$ ethanol at temperature $50^{\circ} \mathrm{C}$ for percent oil yield from rambutan seeds.

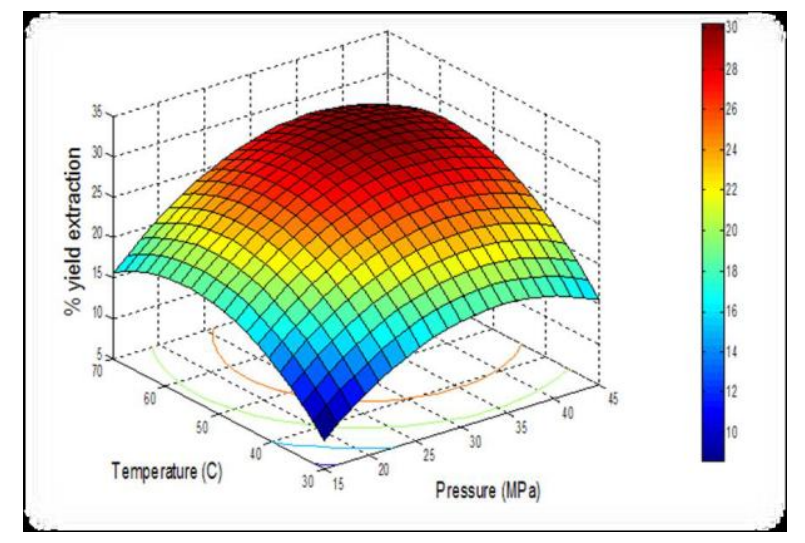

Fig. 4. Surface plot of temperature and pressure at $95 \%$ ethanol with $10 \mathrm{ml}$ for percent oil yield from rambutan seeds.

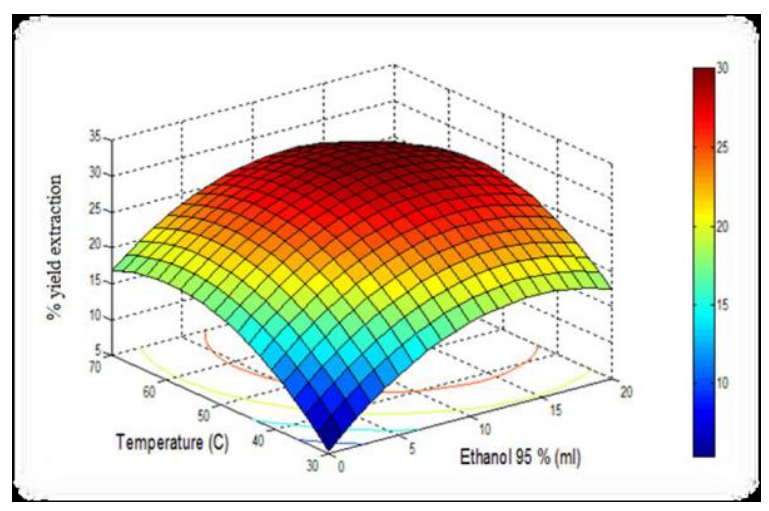

Fig. 5. Surface plot of volume of $95 \%$ ethanol and temperature at pressure $30 \mathrm{MPa}$ for percent oil yield from rambutan seeds.

The surface plot in Fig. 5 revealed that the amounts of extracted oil occurred increase from without ethanol to $10 \mathrm{ml}$ of $95 \%$ ethanol. Percent oil yields decreased inversely with amount of $95 \%$ ethanol more than $10 \mathrm{ml}$. As a result, propose statistical model is adequate for predicting percent oil yield from rambutan seeds using $\mathrm{ScCO}_{2}$, it was calcululated from the equation (1) and gave the highest oil yield 30.38 at pressure $34.8 \mathrm{MPa}$, temperature $56.7^{\circ} \mathrm{C}$, and using $14.5 \mathrm{ml}$ of $95 \%$ ethanol at $2 \mathrm{~h}$ extraction time as shown in Fig. 5. From experment, the result reported that the highest oil yield was 28.42 at pressure $30 \mathrm{MPa}$, temperature $50^{\circ} \mathrm{C}$, and using $10 \mathrm{ml}$ of $95 \%$ ethanol at $2 \mathrm{~h}$ extraction time. Also, the predicted and experimental values were not significantly different. Therefore, the $\mathrm{ScCO}_{2}$ extraction using RSM is an appropriate method for oil extraction from plant.

\section{Comparison of Percent Oil Yields from Various Extraction Methods}

The percent oil yields were extracted from rambutan seeds at different extraction methods (maceration, soxhlet and $\mathrm{ScCO}_{2}$ ) were presented in Fig. 6.

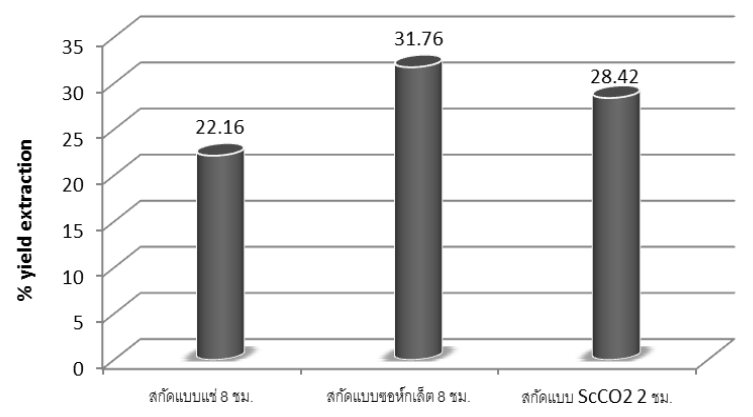

Fig. 6. Comparison of percent oil yields from various extraction methods.

As described in Fig. 6, the maximum of percent oil yields from $\mathrm{ScCO}_{2}$ extraction, soxhlet extraction and maceration were compared, it showed that oil yield were 22.16, 31.76, $28.42 \%$ from rambutan seeds, respectively. Thus, $\mathrm{ScCO}_{2}$ (pressure $30 \mathrm{MPa}$, temperature $56.7^{\circ} \mathrm{C}$, amount of $95 \%$ ethanol in volume $10 \mathrm{ml}$ and extraction times $2 \mathrm{hr}$ ) extracted oil from rambutan seeds was higher than that from maceration (extraction times $8 \mathrm{hr}$ ) and less than a bit of soxhlet (extraction times $8 \mathrm{hr}$ ) due to shorter extraction times. Hence, the $\mathrm{ScCO}_{2}$ extraction was an innovation technique for green technology should be an alternative competitively oil extraction from natural seeds.

\section{CONCLUSION}

The RSM was used to determine the optimum process parameters that high oil yield. It showed that the effects of pressure, temperature and the amount of ethanol as co-solvent were significant in oil yield. Quadratic model were used in predicting all the responses. The optimal conditions based on both individual and combination all responses were determined. Results showed that predicted and experimental values were not significantly different. Therefore, it is suggested the models obtained can be used to optimise the process of oil extraction from rambutan seeds and the $\mathrm{ScCO}_{2}$ methodology could be applied in the extraction of oil from waste seeds in the canned fruit industry.

\section{ACKNOWLEDGMENT}

The author thanks the National Research Council of Thailand (NRCT) for financial support of this work and 
Thailand Toray Science Foundation (TTSF) and Faculty of Graduate Studies, Mahidol University for financial support of this conference. I also thank to Faculty of Engineering, Mahidol University for supported equipment and work place.

\section{REFERENCES}

[1] L. P. Leong and G. Shui, "An investigation of antioxidant capacity of fruits in Singapore markets," J. Food Chem., vol. 76, pp. 69-75, 2002.

[2] J.M.Nzikou, M. M. Tsieri, E. Matouba,J.M. Ouamba,C. Kapseu, M. Parmentier, and S. Desobry, "A study on gumbo seed grown in Congo Brazzaville for its food and Industrial applications," Afr. J. Biotechn., vol. 5, pp. 2469-2474, 2006.

[3] T. Sumate, A. Adulsman, and S. Sutthisak, "Application of Mango (Mangifera indica L.) Seed Extracts with Lactic acid for Reducing Bacteria in Meat," J. Food Chemistry, vol. 76, pp. 76-82, 2010.

[4] L. Z. Cheng, K. Chen, Y. W. Zeng, and Y. H. Peng, "Nutritional composition of Canarium pimela L. kernel," J. Food Chem., vol. 125, pp. 692-695, 2010.

[5] A. Abdalla, S. Darwish, and E. Ayad, "Egyptian mango by-product 1, Compositional quality of mango seed kernel," J. Food Chemistry, vol. 103, no. 4, pp. 1134-1140, 2007.

[6] M. W. Marisa, "Ascorbic acid and mineral composition longan (Dimocarpus longan), lychee(Litchi chinensis) and rambutan (Nephelium lappaceum) cultivars grown in Hawaii," J. Food Compos. Anal., vol. 19, pp. 655-66, 2006.

[7] M. S. Liza, R. A. A. Rahman, B. Mandana, S. Jinap, A. Rahmat, I. Zaidul, and A. I. Hamid, "Supercritical carbon dioxide extraction of bioactive flavonoid from Strobilanthes crispus (PecahKaca)," J. Food Bioprod. Process, vol. 88, pp. 319-326, 2010.

[8] B. Li, Y. Xu, Y. X. Jin, Y. Y. Wu, and Y. Y. Tu, "Response surface optimization of supercritical fluid extraction of kaempferol glycosides from tea seed cake," Ind. Crop. Pro, vol. 32, pp. 123-128, 2010.

[9] W. Liu, Y. J. Fu, Y. G. Zu, M. H. Tong, N. Wu, X. L. Liu, and S. Zhang, "Supercritical carbon dioxide extraction of seed oil from Opuntia dillenii Haw and its antioxidant activity," J. Food Chem, vol. 114, pp. 334-339, 2009.

[10] S. S. H. Rizvi, "Supercritical fluid extraction - Fundamental principles and modeling methods," Food Technology, vol. 40, no. 6, pp. 55-65, 1986.

[11] V. Wong, S. G. Wyllie, C. P. Cornwell, and D. Tronson, "Supercritical fluid extraction (SFE) of monoterpenes from the leaves of Melaleuca alternifolia (Tea Tree)," Molecules, vol. 6, pp. 92-103. 2001.

[12] M. Sajfrtová, I. Ličková, M. Wimmerová, H. Sovová, and Z. Wimmer, "supercritical carbon dioxide extraction from sea buckthorn (Hippopha rhamnoides L.) seeds,” Int. J. Mol. Sci, vol. 11, pp. 1842-1850, 2010.

[13] M. Bimakr, R. A. Rahman, F. S. Taip, A. Ganjloo, L. M. Salleh, J. Selamat, A. Hamid, and I. Zaidul, "Comparison of different extraction methods for the extraction of major bioactive flavonoid compounds from spearmint (Mentha spicata L.) leaves," Food Bioprod. Process, vol. 89, pp. 67-72, 2011.

[14] Q. Lang and C. M. Wai, "Supercritical fluid extraction in herbal and natural product studies-a practical review," Talanta, vol. 53, pp. $771-782,2001$

[15] X. Xua, J. Dong, X. Mua, and L. Sun, "Supercritical $\mathrm{CO}_{2}$ extraction of oil, carotenoids, squalene and sterols from lotus (Nelumbo nucifera
Gaertn) Bee pollen," J. Food and Bioproducts Processing, vol. 89, no. 1, pp. 47-52, 2011

[16] N. S. Lee, "Herbal Extraction by using Supercritical carbon dioxide," Faculty of Phamacy, Srinakharintharawiroj University, Thailand, $J$. Pharmacy, vol. 1, pp. 15-20, 2005.

[17] M. Sun and F. Temelli, "Supercritical carbon dioxide extraction of carotenoids from carrot using canola oil as a continuous co-solvent," $J$. Supercritical Fluids, vol. 37, pp. 397-408, 2006.

[18] R. Thanyaporn, T. Supawan, and N. Somkiat, "Utilization of Supercritical $\mathrm{CO}_{2}$ in Essential oil extraction," J. Food and Bioproducts Processing, vol. 80, no. 2, pp. 43-49, 2009.

[19] A. Donelian, L. Carlson, T. Lopes, and R. Machado, "Comparison of extraction of patchouli (Pogostemon cablin) essential oil with supercritical $\mathrm{CO}_{2}$ and by steam distillation," J. Supercritical Fluids, vol. 48, pp. 15-20, 2009

[20] J. M. D. Valle, O. Rivera, M. Mattea, L. Ruetsch, and J. Daghero, “A. Flores, Supercritical $\mathrm{CO}_{2}$ processing of pretreated rosehip seeds: effect of process scale on oil extraction kinetics," J. Supercritical Fluid, vol. 31, pp. 159-174, 2004.

[21] S. Ibanoglu and P. ainsworth, "Effect of canning on the starch gelatinization and protein in vitro digestibility of tarhana, a wheat flour-based mixture," J. Food Engineering, vol. 64, pp. 243-247, 2004

[22] M. Pinelo, M. Rubilar, M. Jerez, J. Sineiro, and M. J. Nunez, "Effect of solvent, temperature, and solvent-to-solid ratio on the total phenolic content and antiradical activity of extracts from different components of grape pomace," J. Agricultural and Food Chemistry, vol. 53, pp. 2111-2117, 2005.

[23] Z. J. Ping, H. X. lin, L. Ying, and D. H. Yan, "Response Surface Optimization of Nigell glandulifera Freyn seed oil yield by Supercritical carbon dioxide Extraction," J. Integrative Agriculture, vol. 11, no. 1, pp. 151-158, 2012.

[24] Z. J. Wei, A. M. Liao, H. X. Zhang, J. Liu, and S. T. Jianga, "Optimization of supercritical carbon dioxide extraction of silkworm pupal oil applying the response surface methodology," Bioresource Technology, vol. 100, pp. 4214-4219, 2009.

[25] S. Liu, F. Yang, C. Zhang, H. Ji, P. Hong, and C. Deng, "Optimization of process parameters for supercritical carbon dioxide extraction of Passiflora seed oil by response surface methodology," J. Supercritical Fluids, vol. 48, pp. 9-14, 2009.

[26] C. Y. Gan and A. A. Latiff, "Optimisation of the solvent extraction of bioactive compounds from Parkia speciosa pod using response surface methodology," J. Food Chemistry, vol. 124, pp. 1277-1283, 2011.

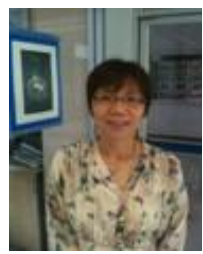

Nuttawan Yoswathana works at Department of Chemical Engineering, Faculty of Engineering, Mahidol University, Thailand. The research fields are bioactive substances and oil extraction from agricultural wastes from industry and Thai herbal using novel techniques such as $\mathrm{ScCO}_{2}$, SCW, HHP and ultrasonic. 